\title{
Population dynamics of mosquito species in a West Nile virus endemic area in Madagascar
}

\author{
Luciano Michaël Tantely ${ }^{1, a,}$, Catherine Cêtre-Sossah ${ }^{2,3,4, a}$, Tsiriniaina Rakotondranaivo ${ }^{1}$, \\ Eric Cardinale ${ }^{2,3,4}$, and Sébastien Boyer ${ }^{1}$ \\ 1 Laboratoire d'Entomologie Médicale, Institut Pasteur de Madagascar, Ambatofotsikely, Antananarivo 101, Madagascar \\ 2 Centre de coopération internationale en recherche agronomique pour le développement (CIRAD), UMR CMAEE, \\ 97491 Sainte Clotilde, La Réunion, France \\ 3 INRA, UMR 1309 CMAEE, 34398 Montpellier, France \\ ${ }^{4}$ Centre de Recherche et de Veille sur les maladies émergentes dans l'Océan Indien (CRVOI), 97490 Sainte Clotilde, \\ La Réunion, France
}

Received 18 July 2016, Accepted 11 January 2017, Published online 30 January 2017

\begin{abstract}
Human and animal serological surveys suggest that West Nile virus (WNV) circulation is widely distributed in Madagascar. However, there are no reported West Nile fever outbreaks or epizootics in the country and only one fatal human case has been reported to date. Currently there is very limited information on the maintenance and the transmission of WNV in Madagascar and particularly on the mosquito species involved in transmission cycles. In 2014, we initiated a study to investigate mosquito species composition, relative abundance, and trophic behavior in Mitsinjo District close to Lake Kinkony, a WNV endemic area in north-western Madagascar. We collected a total of 2519 adult mosquitoes belonging to 21 different species. The most abundant species was Aedeomyia (Aedeomyia) madagascarica Brunhes, Boussès \& da Cunha Ramos, which made up $83 \%$ of all the mosquitoes collected. Mosquito abundance was associated with proximity to the lake (Morafeno and Ankelimitondrotra). Additionally, a correlation was observed between the lake-side biotope and the abundance of mosquito vectors in Morafeno. WNV RNA was detected in one pool of Ae. madagascarica and one pool of Anopheles (Cellia) pauliani Grjebine, suggesting that these two species may be involved in the maintenance and/or transmission of WNV in Madagascar.
\end{abstract}

Key words: Madagascar, Population dynamics, West Nile, Aedeomyia madagascarica, Trophic behavior.

\begin{abstract}
Résumé - Dynamique des populations des espèces de moustiques dans une zone d'endémie du virus de la fièvre du Nil Occidental à Madagascar. Des études sérologiques humaines et animales suggèrent que la circulation du virus de la fièvre du Nil Occidental (VNO) est largement répandue à Madagascar. Toutefois, il n'existe pas de foyers de VNO ni d'épizooties dans le pays et seul un cas humain mortel a été signalé à ce jour. Actuellement, on dispose de très peu d'informations sur l'entretien et la transmission du VNO à Madagascar et en particulier sur les espèces de moustiques impliquées dans les cycles de transmission. En 2014, nous avons entrepris une étude pour étudier la composition des espèces de moustiques, l'abondance relative et le comportement trophique dans le district de Mitsinjo près du lac Kinkony, une zone endémique du VNO dans le nord-ouest de Madagascar. Nous avons recueilli un total de 2519 moustiques adultes appartenant à 21 espèces différentes. L'espèce la plus abondante était Aedeomyia (Aedeomyia) madagascarica Brunhes, Boussès \& da Cunha Ramos, qui constituait $83 \%$ de tous les moustiques collectés. L'abondance de moustiques était associée à la proximité du lac (Morafeno et Ankelimitondrotra). De plus, une corrélation a été observée entre le biotope bordure du lac et l'abondance de moustiques vecteurs à Morafeno. De l'ARN du VNO a été détecté dans un pool d'Ae. madagascarica et un pool d'Anopheles (Cellia) pauliani Grjebine suggérant que ces deux espèces peuvent être impliquées dans le maintien et/ou la transmission du VNO à Madagascar.
\end{abstract}

\footnotetext{
${ }^{a}$ These authors contributed equally to this work.

*Corresponding author: lucinambi@pasteur.mg
}

This is an Open Access article distributed under the terms of the Creative Commons Attribution License (http://creativecommons.org/licenses/by/4.0), which permits unrestricted use, distribution, and reproduction in any medium, provided the original work is properly cited 


\section{Introduction}

West Nile virus (WNV) (family Flaviviridae, genus Flavivirus) was first isolated from a woman with febrile illness in the West Nile district of Uganda in 1937 [54]. The virus is transmitted to humans through the bite of a mosquito that has previously acquired the virus by blood-feeding on infected birds. The role of mosquito species in the WNV transmission cycle was first demonstrated in the species Aedes albopictus (Skuse) in 1943 [47]. The first isolations from human sera occurred in Egypt and Israel in 1951 [20, 23]. Subsequent events, including the emergence of WNV in North America in 1999, its spread westward across the United States, and then throughout the western hemisphere from South America to Canada, as well as repeated outbreaks in Europe [11, 12], suggest that WNV has the largest geographical distribution among the arthropod-borne viruses [24].

In Africa, WNV is endemic and widely distributed [45]. In South Africa, the first evidence of WNV infection was observed in 1958 [38]. Since this initial observation, large human epidemics due to changes in environmental conditions resulting in higher mosquito abundance [62] and high seroprevalence of WNV infection [26] have occurred in South Africa. WNV infections have also been detected in North Africa (Egypt, Tunisia, Algeria, Morocco, Senegal) [4, 9, 49, 52] as well as in Central Africa (Central African Republic, Kenya, Uganda, Nigeria) and Madagascar [4, 9, 14, 40, 52, 53]. Based on genetic differences, WNV strains have been classified in eight lineages, with lineages 1 and 2 being described as pathogenic. WNV Lineage 2 strains, which are endemic in sub-Saharan Africa and Madagascar, were previously considered to be of low pathogenicity $[12,30]$.

Mosquitoes of the genus Culex are the primary vectors of WNV in Africa and Asia due to their vector competence and host preferences. There is geographic variation within the genus due to the presence of locally important Culex $(C x$.) species such as $C x$. pipiens pipiens Linnaeus and Cx. quinquefasciatus Say in Nigeria [44]; Cx. univittatus Theobald in Kenya and South Africa; $C x$. theileri Theobald in South Africa; and Cx. neavei Theobald, $C x$. quinquefasciatus groups, and Cx. poicilipes (Theobald) in Senegal [3, 14]. In Asia, Cx. quinquefasciatus, Cx. tritaeniorhynchus Giles, and Cx. vishnui Theobald predominate [25]. Moreover, WNV vertical transmission has already been demonstrated in the field for several species: Cx. univittatus, Cx. salinarius Coquillett, Cx. tarsalis Coquillett, Cx. erythrothorax Dyar, Cx. stigmatosoma Dyar, and Aedes triseriatus (Say) [13, 39, 41, 42, 61] and experimentally for several other species: Ae. aegypti Linnaeus, Ae. albopictus, Cx. pipiens, Cx. quinquefasciatus, Cx. tritaeniorhynchus, and Cx. modestus Ficalbi [2, 3, 19, 34].

In Madagascar, virus isolation was first reported in 1978 from an endemic parrot species [10] and later from mosquitoes and humans $[16,17]$. Despite serological and virological data demonstrating widespread circulation of WNV across the 18 districts of Madagascar that cover different bioclimatic zones of the country [16,33,36,37,43], neither epidemics nor epizootics of WNV have been reported to date. Only one lethal case due to $\mathrm{WNV}$ infection has been reported in a traveler returning from Madagascar in 2011 [31]. Among the 235 mosquito species described from the country [56], 29 species are widely associated with WNV infection, and they belong to five distinct genera: Aedeomyia (Ad.), Aedes, Anopheles (An.), Culex, and Mansonia [55]. Of these 29 mosquito species associated with WNV infection, 25 are not native to Madagascar [55, 56]: 12 species of genus Culex, 6 of Aedes, 4 of Anopheles, 1 of Aedeomyia, 1 of Coquillettidia, 1 of Lutzia, 2 of Mimomyia, and 1 of Mansonia. According to the proposed system of mosquito vector categorization that included natural infection, vector competence, and field vector-host contact, 4 of these 29 mosquito species were considered as major (Culex quinquefasciatus, Culex tritaeniorhynchus, Culex univitattus, and Mansonia uniformis (Theobald)), nine as candidate vectors (Aedeomyia madagascarica, Aedes albocephalus (Theobald), Aedes circumluteolus (Theobald), Aedes aegypti, Aedes albopictus, Anopheles coustani Laveran, Culex antennatus (Beker), Culex decens Theobald, and Culex pipiens) and the remaining (16 species) as potential vectors [55].

There have been few human and animal serological surveys of circulation rates of WNV in Madagascar in recent decades. In 1990, a first serological survey conducted in 12 regions of Madagascar reported a prevalence of $29.9 \%$ for anti-WNV antibodies in a non-random sample of 5-20 year-old children or young adults [43]. A second survey conducted in 1996 in children under 15 years of age in the highlands, and a third in 1999 along the north-western coast of Madagascar detected a $2.1 \%$ and $10.6 \%$ prevalence of anti-WNV antibodies, respectively [33]. Finally, in 2012-2013, a serological analysis of chicken sentinels was performed in areas close to lakes where domestic, wild, and migratory birds co-exist with humans and potential mosquito vectors were reported. This study revealed differences in the prevalence of anti-WNV antibodies between the two studied districts (Antsalova 29.4\% and Mitsinjo 16.7\%) [36].

These observations are consistent with several possible hypotheses regarding the persistence of enzootic/endemic WNV transmission in Madagascar. The first possibility is that there is a constant potential for contact between $\mathrm{WNV}$ vectors and humans due to the persistence of WNV in wild birds, regardless of the urban/rural setting. A second could be that there are alternating cycles in which urban and rural populations of vectors experience peaks in infection intensity separately, with each being the major contributor to WNV transmission at different times.

To gain a clearer understanding of the involvement of local mosquito populations as putative competent vectors in WNV transmission in Madagascar, a longitudinal entomological survey was carried out around Lake Kinkony. The lake is the second largest lake in Madagascar [28], supporting most of the wetland bird species of western Madagascar [35] with a strong vector density and a high WNV antibody prevalence $[5,36]$. Given these conditions, it is an ideal location to understand the relationships between epizootic and putative sylvatic cycles. This preliminary study aims to determine population dynamics of mosquito species, along with their distribution, abundance, and feeding behavior in the WNV endemic context of Madagascar. 
(A)

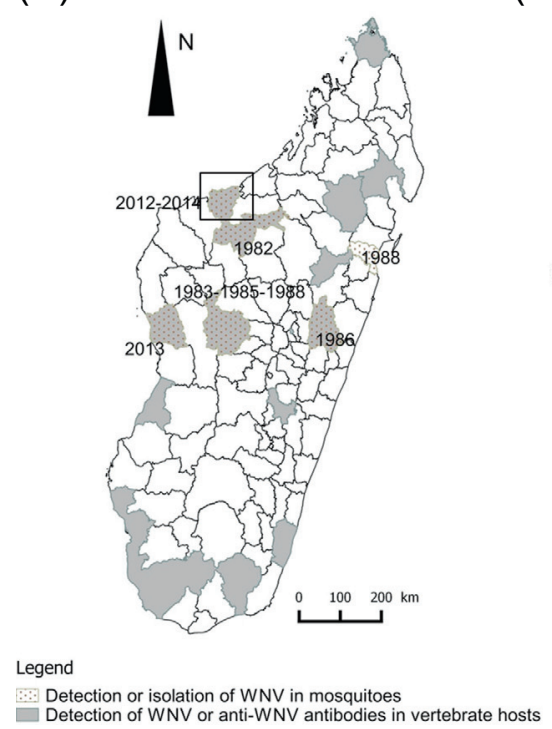

District of Mitsinjo

(B)

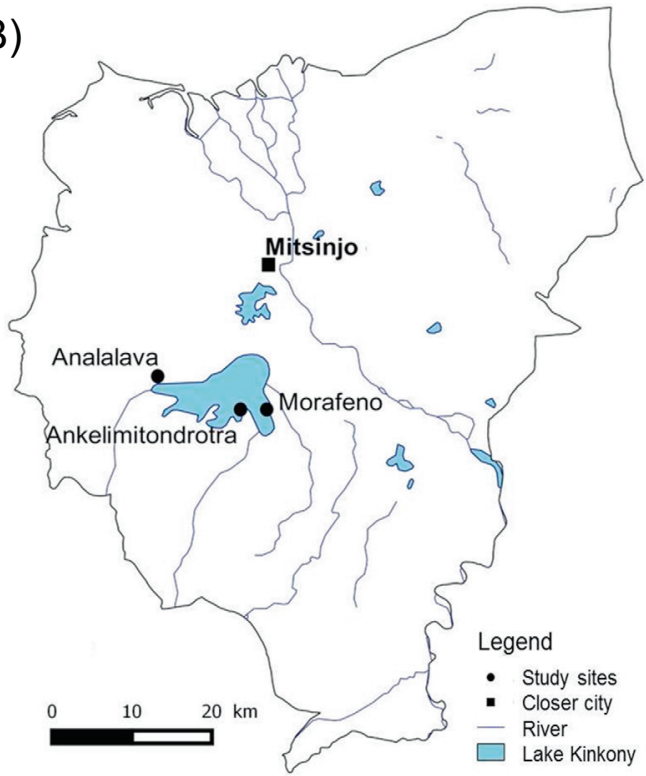

Figure 1. (A) Overall WNV detection in Madagascar (seroprevalence and virus identification) [16, 36, this study]. (B) Location of the study sites, part of the Mitsinjo district (February 2014 to December 2014).

\section{Materials and methods}

\subsection{Study sites}

In the western region of Madagascar, the district of Mitsinjo was chosen based on three criteria: (i) detection of a high WNV seroprevalence in domestic animals with WNV detection in mosquitoes in 2012, (ii) presence of migratory birds in the same area [36], and (iii) ecological features (lake, village, and forest) compatible with WNV transmission between domestic as well as wild wetland and forest birds. Three localities were investigated: Morafeno, Ankelimitondrotra, and Analalava forming an East-West transect across Lake Kinkony (Fig. 1). Morafeno, the most easterly village $\left(16^{\circ} 08^{\prime} 74.6^{\prime \prime} \mathrm{S}, 45^{\circ} 55^{\prime} 17.5^{\prime \prime} \mathrm{E}\right)$, is surrounded by the lake, $100 \mathrm{~m}$ from the lakeside with a landscape made of jujube, tamarind dry forest, and food crops. Ankelimitondrotra $\left(16^{\circ} 08^{\prime} 86.7^{\prime \prime} \mathrm{S}, 45^{\circ} 52^{\prime} 97.3^{\prime \prime} \mathrm{E}\right)$ is located on a peninsula-like projection into the lake. The village is located about $150-200 \mathrm{~m}$ from the lakeside with the landscape predominately composed of jujube and tamarind dry forest as well. A large area of swamp and marshland with aquatic plants is observed between Morafeno and Ankelimitondrotra as described by Andriamasimanana and Rabarimanana [1]. The village of Analalava, the most westerly village $\left(16^{\circ} 08^{\prime} 35.7^{\prime \prime} \mathrm{S}, 45^{\circ} 42^{\prime} 02.5^{\prime \prime} \mathrm{E}\right)$, is located $1 \mathrm{~km}$ from the lakeside with a landscape consisting of jujube, mango, tamarind forest, and savannah dominated by Satrana palm. The average outside temperature is greater than $20{ }^{\circ} \mathrm{C}$ through the year and can exceed $25^{\circ} \mathrm{C}$ during the wet season (September to May). The highest rainfall (200 mm-400 mm a year) was observed between January and March, while the lowest rainfall $(<15 \mathrm{~mm}$ a year) is during the dry season (May and October) [8].
Fishing is the main occupational activity in Morafeno and Ankelimitondrotra; domestic animals (dogs) and livestock (cattle, sheep, goats, pigs, and poultry) are present in all three villages.

\subsection{Longitudinal entomological survey}

Mosquitoes were sampled every two months from February to December 2014 using CDC-light traps (CDC miniature light trap, BioQuip Products, Inc, Rancho Dominguez, USA) (12 in total) for the determination of mosquito population dynamics and poultry-baited BG sentinel traps (BGS traps) (BioQuip Products, USA) (five to six in total) positioned from 6:00 pm to 5:00 am. A longitudinal serological survey of chickens was performed concurrently. Both mosquito traps were distributed in three distinct ecosystems: forest-village transition zone, within village, and lakeside for one night of capture in each village (four light traps and two BG sentinels per ecosystem). The average distance between each ecosystem is about $100 \mathrm{~m}$, except for Analalava where the distance between village and lakeside is $1 \mathrm{~km}$. In August 2014, BG sentinel traps were not used in the village of Analalava due to security concerns.

Each mosquito specimen was morphologically identified by microscopy in the field and in the laboratory on a chilled table, after freezing in liquid nitrogen, based on morphological keys: the unpublished Fontenille key and the Brunhes key [6]. After identification, insects were pooled (1-10 individuals) per species, sex, and blood-feeding status of female (bloodengorged or not engorged), per trap and per zone. They were stored in liquid nitrogen in the field and stored at $-80{ }^{\circ} \mathrm{C}$ in the laboratory. The host origin of the blood meals of 33 engorged mosquitoes collected in CDC-light traps was 
Table 1. Abundance of the 21 mosquito species collected at the adult stage between February 2014 and August 2014 in each village.

\begin{tabular}{|c|c|c|c|c|c|c|c|c|c|}
\hline & \multicolumn{3}{|c|}{ Analalava } & \multicolumn{3}{|c|}{ Ankelimitondrotra } & \multicolumn{3}{|c|}{ Morafeno } \\
\hline & $\mathrm{BG}$ & LT & $\begin{array}{c}\text { Pools } \\
\text { positive }\end{array}$ & BG & LT & $\begin{array}{c}\text { Pools } \\
\text { positive }\end{array}$ & BG & LT & $\begin{array}{c}\text { Pools } \\
\text { positive }\end{array}$ \\
\hline Aedeomyia furfurea (Enderlein) & 1 & 0 & $0 / 1$ & 1 & 11 & $0 / 8$ & 0 & 7 & $0 / 5$ \\
\hline Aedeomyia madagascarica Brunhes, Boussès \& da Cunha Ramos* & 0 & 17 & $0 / 4$ & 31 & 595 & $0 / 57$ & 252 & 1159 & $1 / 108$ \\
\hline Aedeomyia sp. & 0 & 0 & 0 & 0 & 10 & $0 / 1$ & 0 & 0 & 0 \\
\hline Aedes albodorsalis Fontenille and Brunhes* & 1 & 0 & $0 / 1$ & 0 & 0 & 0 & 0 & 0 & 0 \\
\hline Aedes argenteopunctatus (Theobald) & 0 & 0 & 0 & 0 & 1 & $0 / 1$ & 0 & 0 & 0 \\
\hline Aedes sp. & 5 & 1 & $0 / 3$ & 1 & 0 & $0 / 1$ & 0 & 0 & 0 \\
\hline Anopheles coustani Laveran* & 0 & 5 & $0 / 4$ & 1 & 10 & $0 / 5$ & 0 & 11 & $0 / 5$ \\
\hline Anopheles funestus Giles* & 0 & 0 & 0 & 0 & 2 & $0 / 2$ & 1 & 5 & $0 / 3$ \\
\hline Anopheles gambiae Giles* & 2 & 26 & $0 / 7$ & 2 & 2 & $0 / 4$ & 2 & 13 & $0 / 11$ \\
\hline Anopheles maculipalpis Giles & 0 & 6 & $0 / 4$ & 0 & 0 & 0 & 0 & 1 & $0 / 1$ \\
\hline Anopheles mascarensis de Meillon & 5 & 5 & $0 / 3$ & 0 & 0 & 0 & 0 & 0 & 0 \\
\hline Anopheles pauliani Grjebine* & 15 & 1 & $0 / 2$ & 1 & 1 & $0 / 2$ & 2 & 37 & $1 / 13$ \\
\hline Anopheles pharoensis Theobald* & 0 & 7 & $0 / 1$ & 0 & 26 & $0 / 4$ & 3 & 30 & $0 / 7$ \\
\hline Anopheles squamosus/cydippis* & 4 & 12 & $0 / 5$ & 0 & 4 & $0 / 1$ & 4 & 12 & 3 \\
\hline Anopheles rufipes (Gough) & 0 & 2 & $0 / 2$ & 0 & 0 & 0 & 0 & 0 & 0 \\
\hline Anopheles sp. & 0 & 0 & 0 & 1 & 1 & $0 / 1$ & 0 & 2 & 1 \\
\hline Culex antennatus (Becker)* & 0 & 15 & $0 / 4$ & 0 & 4 & $0 / 3$ & 0 & 10 & 2 \\
\hline Culex bitaeniorhyncus Giles* & 0 & 1 & $0 / 1$ & 0 & 4 & $0 / 1$ & 0 & 1 & 1 \\
\hline Culex decens Theobald & 2 & 13 & $0 / 5$ & 0 & 0 & 0 & 0 & 1 & 1 \\
\hline Culex poicilipes (Theobald) ${ }^{\mu}$ & 2 & 0 & $0 / 1$ & 1 & 4 & $0 / 4$ & 0 & 14 & 1 \\
\hline Culex tritaeniorhyncus Giles* & 3 & 2 & $0 / 3$ & 0 & 3 & $0 / 1$ & 0 & 11 & 5 \\
\hline Culex univittatus Theobald* & 3 & 3 & $0 / 3$ & 1 & 0 & $0 / 1$ & 0 & 3 & 3 \\
\hline Culex sp. & 1 & 0 & $0 / 1$ & 1 & 0 & $0 / 1$ & 1 & 3 & 2 \\
\hline Mansonia uniformis (Theobald)* & 14 & 12 & $0 / 7$ & 2 & 12 & $0 / 6$ & 7 & 5 & 5 \\
\hline Uranotaenia sp. & 0 & 3 & $0 / 2$ & 0 & 0 & 0 & 0 & 0 & 0 \\
\hline Total & 58 & 131 & $0 / 64$ & 43 & 690 & $0 / 104$ & 272 & 1325 & $2 / 177$ \\
\hline
\end{tabular}

BG: Biogent sentinel. LT: light trap.

* Mosquito species collected in November 2012 in the same area [5].

Bold: mosquito species found naturally infected with WNV in Madagascar [16, 36].

${ }^{\mu}$ Mosquito species found naturally infected with WNV in Africa [59].

determined by the Beier method [4]. In all, seven vertebrate hosts were tested (human, rat, cow, pig, sheep, chicken, and dog) by a direct enzyme-linked immunosorbent assay (ELISA).

\subsection{Screening mosquitoes for West Nile virus}

The abdomens of 1825 unfed monospecific female mosquitoes were dissected, pooled, and ground up in $350 \mu \mathrm{L}$ of Minimal Essential (MEM) cell culture medium (Gibco Life Technologies, USA) containing a mixture of $1000 \mathrm{U} / \mathrm{mL}$ penicillin, $1 \mathrm{mg} / \mathrm{mL}$ streptomycin, and $25 \mu \mathrm{g} / \mathrm{mL}$ amphotericin B (Sigma, USA) with two 3-mm diameter stainless steel beads (Loudet, France) for $30 \mathrm{~s}$ using the TissueLyser system (Qiagen, USA). Total RNA was extracted using the NucleoSpin RNA Virus kit (Macherey-Nagel, Germany). For WNV RNA detection, a capsid-based Taqman probe real-time PCR system able to detect WNV lineages 1 and 2 was used with AgPath-ID ${ }^{\mathrm{TM}}$ One-Step RT-PCR Reagents (Ambion, Life Technologies, USA) [32] on a 7500 Real-time PCR system (Applied Biosystems, USA). A lineage 2 positive control was kindly provided by Dr S. Lecollinet (ANSES, France) and included in each of the tests for plate validation.

\subsection{Statistical analysis}

Data analyses were performed in $\mathrm{R}$ version 2.10.1 (R Foundation for Statistical Computing (http://www. r-project.org), and $p \leq 0.05$ denoted statistical significance. The mosquito community structure at the different study sites and transects was analyzed using the following approaches: diversity using a Shannon equitability index $\left(H^{\prime}\right)$, and similarity of mosquito fauna using the Jaccard Index of similarity $(J)$, based on the presence/absence of data only. We used the number of mosquito adults caught as the numeric surrogate for analyzing the effect of the types of trap, months, localities, and biotopes with a multi-way ANOVA (analysis of variance).We used Tukey's honest significant difference (HSD) to determine which pairs of means were significantly different.

\section{Results}

\subsection{Mosquito abundance, species diversity, and trophic preferences}

A total of 2519 specimens belonging to 21 mosquito species and 6 genera were identified (Tables 1 and 2). At each study site, no significant difference in terms of proportion of 
Table 2. Abundance of the 21 mosquito species collected at the adult stage in the three biotopes (villages/forest/lakeside) for each village.

\begin{tabular}{|c|c|c|c|c|c|c|c|c|c|}
\hline \multirow[t]{2}{*}{ Species } & \multicolumn{3}{|c|}{ Analalava } & \multicolumn{3}{|c|}{ Ankelimitondrotra } & \multicolumn{3}{|c|}{ Morafeno } \\
\hline & Forest & Lakeside & Village & Forest & Lakeside & Village & Forest & Lakeside & Village \\
\hline Aedeomyia furfurea & 0 & 1 & 0 & 4 & 6 & 2 & 6 & 1 & 0 \\
\hline Aedeomyia madagascarica* & 2 & 6 & 9 & 246 & 209 & 171 & 326 & 582 & 503 \\
\hline Aedeomyia sp. & 0 & 0 & 0 & 0 & 0 & 10 & 0 & 0 & 0 \\
\hline Aedes albodorsalis* & 0 & 1 & 0 & 0 & 0 & 0 & 0 & 0 & 0 \\
\hline Aedes argenteopunctatus & 0 & 0 & 0 & 0 & 0 & 1 & 0 & 0 & 0 \\
\hline Aedes sp. & 1 & 0 & 5 & 0 & 1 & 0 & 0 & 0 & 0 \\
\hline Anopheles coustani* & 1 & 0 & 4 & 1 & 1 & 9 & 1 & 6 & 4 \\
\hline Anopheles funestus* & 0 & 0 & 0 & 1 & 1 & 0 & 0 & 2 & 4 \\
\hline Anopheles gambiae* & 1 & 1 & 26 & 1 & 3 & 0 & 3 & 4 & 8 \\
\hline Anopheles maculipalpis & 1 & 0 & 5 & 0 & 0 & 0 & 0 & 1 & 0 \\
\hline Anopheles mascarensis & 1 & 0 & 9 & 0 & 0 & 0 & 0 & 0 & 0 \\
\hline Anopheles pauliani* & 0 & 0 & 16 & 2 & 0 & 0 & 10 & 12 & 17 \\
\hline Anopheles pharoensis* & 0 & 0 & 7 & 19 & 2 & 5 & 4 & 11 & 18 \\
\hline Anopheles rufipes & 0 & 0 & 2 & 0 & 0 & 0 & 0 & 0 & 0 \\
\hline Anopheles squamosus/cydippis* & 4 & 0 & 12 & 0 & 1 & 3 & 0 & 12 & 4 \\
\hline Anopheles sp. & 0 & 0 & 0 & 0 & 1 & 1 & 0 & 1 & 1 \\
\hline Culex antennatus* & 7 & 1 & 7 & 1 & 2 & 1 & 0 & 6 & 4 \\
\hline Culex bitaeniorhyncus* & 0 & 1 & 0 & 2 & 0 & 2 & 0 & 1 & 0 \\
\hline Culex decens & 2 & 2 & 11 & 0 & 0 & 0 & 0 & 0 & 1 \\
\hline Culex poicilipes $^{\mu}$ & 0 & 2 & 0 & 1 & 3 & 1 & 0 & 9 & 5 \\
\hline Culex tritaeniorhyncus* & 0 & 0 & 5 & 3 & 0 & 0 & 0 & 3 & 8 \\
\hline Culex univittatus* & 2 & 0 & 4 & 0 & 0 & 1 & 0 & 0 & 3 \\
\hline Culex sp. & 1 & 0 & 0 & 1 & 0 & 0 & 1 & 3 & 0 \\
\hline Mansonia uniformis* & 2 & 6 & 18 & 5 & 6 & 3 & 0 & 8 & 4 \\
\hline Uranotaenia sp. & 0 & 1 & 2 & 0 & 0 & 0 & 0 & 0 & 0 \\
\hline Total & 25 & 22 & 142 & 287 & 236 & 210 & 351 & 662 & 584 \\
\hline
\end{tabular}

* Mosquito species collected in November 2012 in the same area [5].

Bold: mosquito species found naturally infected with WNV in Madagascar [16, 36].

${ }^{\mu}$ Mosquito species found naturally infected with WNV in Africa [59].

mosquitoes was observed between CDC-light traps and chicken-baited BG sentinel traps (Table 3; $d f=1, F=0.037$, $p>0.8$ ). When data from the three villages collected during six separate field samplings in a one-year period were combined, the species accumulation curve tended toward a plateau (Fig. 4). Two species of the genus Aedeomyia made up $82.33 \%$ of the adult catches. Ten and seven species of Anopheles and Culex genera accounted for $10.32 \%$ and $4.00 \%$ of the collection, respectively. The remaining, lowfrequency, mosquito species captured $(2.54 \%)$ consisted of species from the genera Aedes, Mansonia, and Uranotaenia. Greater species richness was found in Analalava $\left(H^{\prime}=2.94\right)$, followed by Morafeno $\left(H^{\prime}=2.77\right)$ and Ankelimitondrotra $\left(H^{\prime}=2.70\right)$. Similarity in species diversity was much higher $(J=0.82)$ between Morafeno and Ankelimitondrotra than between Morafeno and Analalava $(J=0.75)$, or between Ankelimitondrotra and Analalava $(J=0.61)$.

Mosquito abundance, driven mainly by the highly abundant species Ad. madagascarica, seemed to be associated with villages that are close to the lake (i.e. Morafeno and Ankelimitondrotra (Table 3; $d f=2, F=4.448, p<0.01$ ), with higher mosquito density observed in Morafeno (Tukey HSD tests: $p<0.001)$.
Correlation between lakeside biotope and the abundance of mosquito vectors was observed in Morafeno (Table 3; $d f=17$, $F=17.89, \quad p<0.001)$. Post hoc tests showed that this difference is only driven by the differences of Anopheles density between forest and lake (Tukey HSD tests: $p<0.001$ ) and between forest and village (Tukey HSD tests: $p<0.001$ ). No difference in mosquito density was observed for each of the mosquito species between lake and village in Morafeno (Tukey HSD tests: $p>0.05$ ). No significant relationship between biotopes/ecotypes and mosquito abundance was observed in Ankelimitondrotra (Table 3; $d f=18, F=0.848$, $p>0.64$ ) and Analalava (Table $3 ; d f=15, F=0.00, p=1$ ). We noted that in Ankelimitondrotra, the forest and lakeside ecosystems are located in close proximity, as the village is surrounded by the lake, while for Analalava, the lakeside biotope is located farther (approximately $1000 \mathrm{~m}$ ) from the village and forest.

The highest and lowest abundance of caught adult mosquitoes was observed, respectively, in the village of Morafeno and the village of Analalava; with a high number of Ad. madagascarica obtained in Morafeno and Ankelimitondrotra (Table 3; $d f=20, F=2.61, p<0.001$ ). This species made up $81.54 \%(2054 / 2519)$ of the overall 
Table 3. Analysis of variance to examine the effect of trap types (B), months (C), localities (D), and biotope nature (E) on the heterogeneity of mosquito species (A) in Lake Kinkony.

\begin{tabular}{|c|c|c|c|c|c|}
\hline & $d f$ & Sum $\mathrm{Sq}$ & Mean Sq & $F$ value & $\operatorname{Pr}(>F)$ \\
\hline \multicolumn{6}{|c|}{ a-Combined localities } \\
\hline $\mathrm{A}$ & 20 & 0.0342 & 0.001709 & 2.612 & $0.00012 * * *$ \\
\hline B & 1 & 0.0000 & 0.000024 & 0.037 & 0.84746 \\
\hline $\mathrm{C}$ & 5 & 0.0014 & 0.000277 & 0.423 & 0.83288 \\
\hline $\mathrm{D}$ & 2 & 0.0058 & 0.002910 & 4.448 & $0.01180 *$ \\
\hline $\mathrm{E}$ & 2 & 0.0019 & 0.000948 & 1.449 & 0.23495 \\
\hline $\mathrm{A} \times \mathrm{B}$ & 13 & 0.0011 & 0.000088 & 0.135 & 0.99989 \\
\hline $\mathrm{A} \times \mathrm{C}$ & 45 & 0.0445 & 0.000988 & 1.510 & $0.01622 *$ \\
\hline $\mathrm{A} \times \mathrm{D}$ & 29 & 0.0514 & 0.001772 & 2.709 & $2.50 \mathrm{e}-06^{* * *}$ \\
\hline $\mathrm{A} \times \mathrm{E}$ & 29 & 0.1670 & 0.005759 & 8.804 & $<2.00 \mathrm{e}-16^{* * *}$ \\
\hline $\mathrm{R}$ & 2293 & 1.5000 & 0.000654 & & \\
\hline \multicolumn{6}{|c|}{ b-Morafeno } \\
\hline A & 16 & 0.0894 & 0.005588 & 5.607 & $7.09 \mathrm{e}-12 * * *$ \\
\hline $\mathrm{C}$ & 5 & 0.0025 & 0.000490 & 0.492 & 0.78262 \\
\hline $\mathrm{E}$ & 2 & 0.0033 & 0.001672 & 1.677 & 0.18723 \\
\hline $\mathrm{A} \times \mathrm{C}$ & 22 & 0.0430 & 0.001956 & 1.962 & $0.00493 * *$ \\
\hline $\mathrm{A} \times \mathrm{E}$ & 17 & 0.3031 & 0.017832 & 17.892 & $<2 \mathrm{e}-16 * * *$ \\
\hline $\mathrm{R}$ & 1505 & 1.5000 & 0.000997 & & \\
\hline \multicolumn{6}{|c|}{ c-Ankelimitondrotra } \\
\hline A & 15 & $2.000 \mathrm{e}-29$ & $1.600 \mathrm{e}-30$ & 0.012 & 1.00000 \\
\hline $\mathrm{C}$ & 4 & $4.920 \mathrm{e}-27$ & $1.230 \mathrm{e}-27$ & 8.796 & $6.34 \mathrm{e}-07^{* * *}$ \\
\hline $\mathrm{E}$ & 2 & $3.000 \mathrm{e}-28$ & $1.515 \mathrm{e}-28$ & 1.084 & 0.33893 \\
\hline $\mathrm{A} \times \mathrm{C}$ & 10 & $3.350 \mathrm{e}-27$ & $3.349 \mathrm{e}-28$ & 2.395 & $0.00852 * *$ \\
\hline $\mathrm{A} \times \mathrm{E}$ & 18 & $2.130 \mathrm{e}-27$ & $1.185 \mathrm{e}-28$ & 0.848 & 0.64330 \\
\hline $\mathrm{R}$ & 670 & $9.367 \mathrm{e}-26$ & $1.398 \mathrm{e}-28$ & & \\
\hline \multicolumn{6}{|c|}{ d-Analalava } \\
\hline A & 18 & $8.530 \mathrm{e}-30$ & $4.739 e-31$ & 0.402 & 0.985 \\
\hline $\mathrm{C}$ & 5 & $0.000 \mathrm{e}+00$ & $1.000 \mathrm{e}-34$ & 0.000 & 1.000 \\
\hline $\mathrm{E}$ & 2 & $0.000 \mathrm{e}+00$ & $0.000 \mathrm{e}+00$ & 0.000 & 1.000 \\
\hline $\mathrm{A} \times \mathrm{C}$ & 18 & $0.000 \mathrm{e}+00$ & $0.000 \mathrm{e}+00$ & 0.000 & 1.000 \\
\hline$A \times E$ & 15 & $1.000 \mathrm{e}-32$ & $6.000 \mathrm{e}-34$ & 0.000 & 1.000 \\
\hline $\mathrm{R}$ & 118 & $1.392 \mathrm{e}-28$ & $1.179 \mathrm{e}-30$ & & \\
\hline
\end{tabular}

$\times$ shows the effect of interaction between cited factors.

${ }^{*} p=0.05 ;{ }^{* *} p=0.01 ;^{* * *} p=0.001$.

$d f=$ Degrees of freedom; Sum Sq $=$ sum of squares; Mean Sq $=$ mean of squares; $F$ value $=$ value of the $F$ test; $\operatorname{Pr}(>\mathrm{F})=$ probability of the $F$ test.

adult catches with light traps, being rare during the rainy season (November to March) and very abundant during the dry season (Fig. 2). The total amount of mosquitoes and Ad. madagascarica captured gave the same pattern of monthly variation when data from the three villages were combined (Fig. 3) (Table 3; $d f=45, F=1.51, p<0.01$ ). Whereas the peak of abundance of mosquitoes in Ankelimitondrotra was observed in April, the peak in Morafeno occurred in August with a sharp decline afterwards (Fig. 2).

Of the 33 blood meals analyzed from engorged mosquitoes, $15(45 \%)$ of the total amount could not be identified due to the limits of the technique used. As shown in Table 4, most of the identifiable blood meals (11/18) were taken from domestic ruminants (cattle or sheep), six mixed blood meals were from cattle/sheep and one mixed blood meal from chicken/dog.

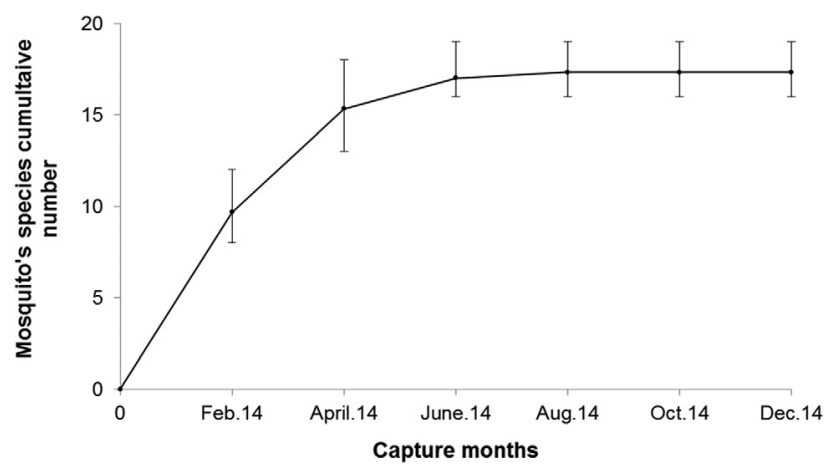

Figure 2. Mosquito species cumulative number for the 21 species caught around Lake Kinkony from February 2014 to December 2014. Standard errors bars indicate the standard deviations. 


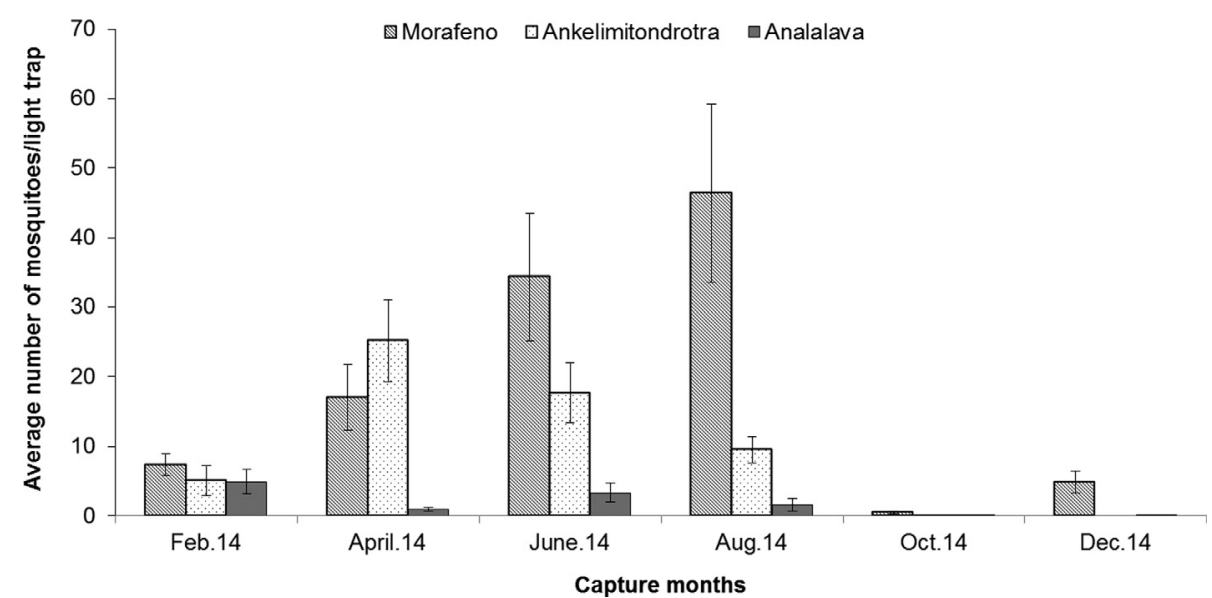

Figure 3. Distribution of all mosquitoes across the villages in the Lake Kinkony area (average number/CDC-light trap), standard error bars indicate standard deviations.

\subsection{Screening mosquitoes for West Nile virus}

Eight mosquito species that have previously been found infected with WNV in Madagascar were collected during our study. Two of these species (An. maculipalpis and Cx. decens) were not collected in one of the localities (Ankelimitondrotra). When WNV genome detection was performed for a total of 346 abdomen pools representing 1825 mosquitoes (177 pools from Morafeno, 104 pools from Ankelimitondrotra, and 65 pools from Analalava), positive detection was observed in two of the tested pools: one pool of Ad. madagascarica (collected in April 2014) and one pool of An. pauliani (collected in August 2014). Both positive pools came from light traps placed near the lakeside in Morafeno.

\section{Discussion}

The species accumulation curve tending toward a plateau suggests that the number of species caught was approaching the total number of mosquito species in the area. Twenty-one mosquito species were collected in our study, a much larger number than the 14 species described in 2012 in the same area [5]. However, we did not collect seven mosquito species belonging to the Aedes, Anopheles, and the Culex genera that were collected near the site Morafeno in November 2012 [5]. This observation might be explained by the limitations of our sampling methods using only CDC-light traps and chicken-baited BG sentinel traps, in contrast to Boyer et al. (2014) in which other types of traps such as cattle-baited nets and backpack aspirators were used [5].

Of the eight mosquito species caught in our study area that were previously known to be infected by WNV in Madagascar $[16,36,55]$, four were recently found WNV-positive in villages near lake areas: Ad. madagascarica and An. coustani near Lake Kinkony and An. pauliani and Ma. uniformis near Lake Soamalipo [36]. In our study, Ad. madagascarica and An. pauliani were the two species found to be positive for WNV. Unfed mosquito abdomens rather than whole specimens were screened for WNV infection. Detecting WNV in the abdomens of unfed mosquitoes suggests the potential for these two species to be involved in the maintenance and/or transmission of WNV in Madagascar. However, to incriminate these species as vectors of WNV transmission, vector competence studies should be undertaken to show infectious virus in the saliva $[18,48]$.

CDC-light traps are suitable for studying mosquito seasonal dynamics as evidenced by data obtained in Morocco [15], in sub-Saharan Africa [40], and in Madagascar [57, 58]. Interestingly, vector populations were abundant during the dry season with a great abundance of Ad. madagascarica (Fig. 3), contrasting with the findings in the central highlands of Madagascar, where WNV mosquito vectors and other arthropod-borne diseases are abundant at the beginning of and during the wet season $[16,57,58]$. Our results would suggest that the abundance of the potential vector Ad. madagascarica is influenced by temperature rather than by rainfall [51]. In Europe, abundance of WNV mosquito vectors was reported to be driven mostly by artificial flooding for human activities (cultivation, hunting, and fishing) rather than rainfall $[2,21]$.

This is the first time that Ad. madagascarica has been trapped in such large numbers in Madagascar, emphasizing its potential role in the WNV endemic cycle around the wetlands of Lake Kinkony. Indeed, species belonging to the genus Aedeomyia were rarely captured with other types of mosquito traps (light or baited traps) in Madagascar [5, 16, $46,58]$. Despite the lack of information on its larval stage biology, the abundance of this species at our study sites, mainly in Morafeno and Ankelimitondrotra, might be explained by the presence of the large swamp and marshland (with aquatic plants) that are favorable larval sites of the genus Aedeomyia [6].

Worldwide, there are seven species in the genus Aedeomyia $[6,22]$ with Ad. africana (absent from Madagascar) reported to be involved in the transmission of WNV in Africa [59]. In Madagascar, three species of the genus Aedeomyia have been collected (Ad. madagascarica, Ad. pauliani, and Ad. furfurea) [56] and previous detection of WNV 


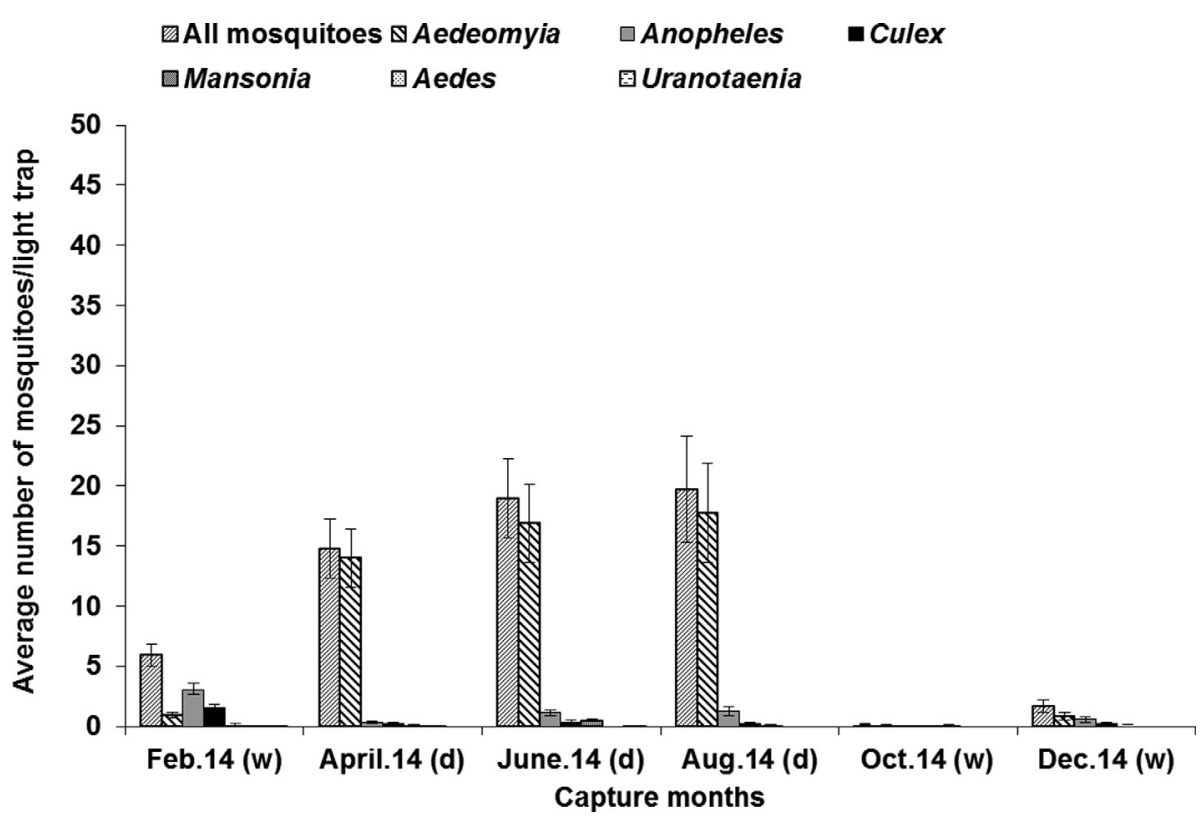

Figure 4. Average number of mosquitoes per light-trap in the Lake Kinkony area, data from the three villages being combined; standard error bars indicate standard deviations, $\mathrm{d}=$ dry season, $\mathrm{w}=$ wet season.

Table 4. Number of mosquitoes captured by poultry-baited BG sentinel traps and results from the blood meal analysis of engorged mosquitoes captured in light traps, including vertebrate host identification.

\begin{tabular}{|c|c|c|c|c|c|c|c|c|}
\hline \multirow[t]{2}{*}{ Genus } & \multicolumn{2}{|c|}{ Capture with BG } & \multirow[t]{2}{*}{ nb. species tested } & \multirow[t]{2}{*}{ nb. pos/nb. tested } & \multicolumn{4}{|c|}{ Antibody tested } \\
\hline & nb. species & nb. adult & & & Sheep & Cattle & Cattle/Sheep ${ }^{\beta}$ & Poultry $/ \operatorname{Dog}^{\beta}$ \\
\hline Aedeomyia* & 2 & 281 & $1^{*}$ & $1 / 1$ & 0 & 0 & 0 & 1 \\
\hline Aedes & 2 & 10 & - & $0 / 3$ & - & - & - & - \\
\hline Anopheles & 7 & 36 & $5^{\mu}$ & $10 / 20$ & 4 & 2 & 4 & 0 \\
\hline Culex & 4 & 19 & $3^{\circ}$ & $7 / 7$ & 1 & 4 & 2 & 0 \\
\hline Mansonia & 1 & 24 & - & $0 / 1$ & - & - & - & - \\
\hline Uranotaenia & 1 & 1 & - & $0 / 1$ & - & - & - & - \\
\hline Total & 17 & 361 & 9 & & 5 & 6 & 6 & 1 \\
\hline
\end{tabular}

* Aedeomyia madagascarica.

${ }^{\mu}$ An. pauliani: three blood meals from sheep and six mixed blood meals from cattle/sheep.

${ }^{\circ}$ Cx. antennatus: two blood meals from sheep and cattle.

${ }^{\beta}$ Mixed blood meal.

$\mathrm{nb}$ : stands for number.

in Ad. madagascarica on the island [36] has been confirmed by this study. This endemic species was recently described at adult stages that are morphologically close to those of Ad. africana [6].

Our results also raise questions as to how An. pauliani intervenes in WNV circulation around Lake Kinkony given its low relative abundance. Indeed, only a small number of this species were previously reported in the western wetlands (Lake Kinkony and Lake Soamalipo) of Madagascar [5]. However, this species might be an important WNV vector in a different biotope such as the village of Mampikony (district of Mampikony, $200 \mathrm{~km}$ east of lake Kinkony) where this species was found to be abundant [46]. An. pauliani is a general feeder [56], but is already considered as a potential vector of WNV due its rarity and to the lack of information on its vector competence [55].
Our results also support ornithophilic blood-feeding behavior, mainly for Ad. madagascarica in this study, in that chicken-baited BG sentinel traps proved to be very attractive for mosquitoes, thus confirming the use of poultry as an alternative to BG-Lure [5]. Indeed, BG sentinel traps were designed to collect anthropophilic mosquitoes by using artificial substances (BG-Lure) which are also present on human skin [29]. This attraction of Ad. madagascarica to poultry is in accordance with blood meal analysis, showing chickens as the blood meal source for this species (Table 4). The use of ELISA for blood meal analysis carries a risk of cross-reactivity but more notably fails to identify many potential hosts, including wild birds, as evidenced by the inability to identify more than $40 \%$ of blood meals from engorged mosquitoes. Further analysis using PCR-based methods targeting cytochrome B or cytochrome 1 genes [27] 
would provide confirmation of host blood meal sources. Unfortunately, at the time of the study, the technique was not routinely used in the laboratory. Our findings highlight the ornithophilic behavior already described for the genus Aedeomyia [6], and uphold the hypothesis of the involvement of ornithophilic mosquito species in the WNV epidemiological cycle [2, 7] and WNV circulation in bird populations in Madagascar [16, 17, 36]. The ornithophilic feeding preferences of Ad. madagascarica suggest this species might be involved in the maintenance of $\mathrm{WNV}$ in the mosquito/bird enzootic cycle, while other mosquito species considered as generalist feeders (Table 4) might serve as bridge vectors between birds and dead-end hosts (mammals) due to the low numbers of bird-to-bird feedings [60].

Finally, our results suggest that the abundance of mosquitoes around households, mainly Ad. madagascarica, depends on the distance between villages and lakes, suggesting mosquito heterogeneity in accordance with WNV incidence between villages around Lake Kinkony [36]. Although currently not documented in this study, more intense WNV transmission in villages near lakes would be expected, as highlighted by WNV detection in mosquitoes in Morafeno, given the correlation between lakeside ecotype and the abundance of $A d$. madagascarica in this village. However, exposure of this species to a viremic host could not be excluded, given that WNV circulation was recently reported in this area [36]. For this reason, Ad. madagascarica is considered as a candidate vector of WNV due to the lack of information on its vector competence [55]. Vector competence studies need to be undertaken to conclude that this species may act as a bridge vector from wild to domestic birds, or vice versa, given that chickens, ducks, and geese are often left wandering during the night, facilitating bird-vector contact at our study sites. To demonstrate the vector competence of this species, the transmission of the virus during the feeding process is required with the determination of the dissemination rate throughout the mosquito body (legs, salivary glands) suggesting virus dissemination and transmission, which are known to depend on temperatures and viral loads [18, 48, 50]. An association with the presence of Ad. madagascarica in areas subject to WNV epizootics and/or epidemics could provide further evidence of its role in transmission.

In conclusion, our findings suggest that Aedeomyia madagascarica and Anopheles pauliani are potential vectors involved in the maintenance and/or transmission of WNV in Madagascar. Further work will provide greater knowledge of the host blood meals of these mosquitoes and better characterize the dynamics of WNV in this region, along with determining the WNV vector competence of these two species.

Acknowledgements. We thank Dr. Thomas Walker and Benjamin Rice for critical reading of the manuscript. This study was conducted and funded as part of Animal Risk, a research program on emerging animal infectious diseases in the Indian Ocean Region, and the Institut Pasteur de Madagascar. We thank all the Mitsinjo district farmers, veterinarians, and veterinary technicians for their participation in the fieldwork. The contents of this publication are the sole responsibility of the authors and do not necessarily reflect the views of the European Commission.

\section{References}

1. Andriamasimanana R, Rabarimanana M. 2011. Analyses de la dégradation du Lac Kinkony pour la conservation du complexe des zones humides Mahavavy, Kinkony, Région Boeny, Madagascar. Madagascar Conservation and Development, 6, 22-28.

2. Balenghien T, Fouque F, Sabatier P, Bicout D. 2006. Horse-, bird-, and human-seeking behavior and seasonal abundance of mosquitoes in a West Nile virus focus of southern France. Journal of Medical Entomology, 43, 936-946.

3. Baqar S. 1993. Vertical transmission of West Nile virus by Culex and Aedes species mosquitoes. American Journal of Tropical Medicine and Hygiene, 48, 757-762.

4. Berthet F, Zeller H, Drouet M, Rauzier J, Digoutte J, Deubel V. 1997. Extensive nucleotide changes and deletions within the envelope glycoprotein gene of Euro-African West Nile viruses. Journal of General Virology, 78, 2293-2297.

5. Boyer S, Tantely ML, Randriamaherijaona S, Andrianaivolambo L, Cardinale E. 2014. Mosquitoes sampling strategy for studying relationships between wild and domestic birds, mosquitoes vectors and human in Madagascar. Archives de l'Institut Pasteur de Madagascar, 71, 1-8.

6. Brunhes J, Boussès $\mathrm{P}$, da Cunha Ramos H. 2011. Les Aedeomyia Theobald, 1901, des régions afrotropicale et malgache (Diptera, Culicidae). Bulletin de la Société Entomologique de France, 116, 99-128.

7. Campbell GL, Marfin AA, Lanciotti RS, Gubler DJ. 2002. West Nile virus. Lancet, 2, 519-529.

8. Chanteau S. 2006. Atlas de la peste à Madagascar. Institut de recherche pour le développement, Institut Pasteur, Agence universitaire de la Francophonie: Paris.

9. Charrel R, Brault A, Gallian P, Lemasson J, Murgue B, Murri S, Pastorino B, Zeller H, de Chesse R, de Micco P, de Lamballerie X. 2003. Evolutionary relationship between Old World West Nile virus strains. Evidence for viral gene flow between Africa, the Middle East, and Europe. Virology Monographs, 315, 381-388.

10. Clerc Y, Coulanges P. 1979. Rapport du laboratoire d'Arbovirus pour 1978. Archives de l'Institut Pasteur de Madagascar, 47, 64-68.

11. Dauphin G, Zientara S, Zeller H, Murgue B. 2006. West Nile: worldwide current situation in animals and humans. Comparative Immunology, Microbiology and Infectious Diseases, 27, 343-355.

12. Donadieu E, Bahuon C, Lowenski S, Zientara S, Coulpier M, Lecollinet S. 2013. Differential virulence and pathogenesis of West Nile viruses. Viruses, 5, 2856-2880.

13. Engler O, Savini G, Papa A, Figuerola J, Groschup M, Kampen H, Medlock J, Vaux A, Wilson A, Werner D, Jöst H, Goffredo M, Capelli G, Federici V, Tonolla M, Patocchi N, Flacio E, Portmann J, Rossi-Pedruzzi A, Mourelatos S, Ruiz S, Vázquez A, Calzolari M, Bonilauri P, Dottori M, Schaffner F, Mathis A, Johnson N. 2013. European surveillance for West Nile virus in mosquito populations. International Journal of Environmental Research and Public Health, 10, 4869-4895.

14. Fall AG, Diaïte A, Lancelot R, Tran A, Soti V, Etter E, Konaté L, Faye O, Bouyer J. 2011. Feeding behaviour of potential vectors of West Nile virus in Senegal. Parasites and Vectors, 4, 1-7.

15. Faraj C, Adlaoui E, Ouahabi S, Rhajaoui M, Fontenille D, Lyagoubi M. 2009. Entomological investigations in the region of the last malaria focus in Morocco. Acta Tropica, 109, 70-73. 
16. Fontenille D. 1989. Arbovirus transmission cycles in Madagascar. Archives de l'Institut Pasteur de Madagascar, $55,1-317$.

17. Fontenille D, Rodhain F, Digoutte JP, Mathiot CH, Morvan J, Coulanges P. 1989. Les cycles de transmission du virus West Nile à Madagascar, Océan Indien. Annales de la Société Belge de Médecine Tropicale, 69, 233-243.

18. Goddard LB, Roth AE, Reisen WK, Scott TW. 2002. Vector competence of California mosquitoes for West Nile virus. Emerging Infectious Diseases, 8, 1385-1391.

19. Goddard LB, Roth AE, Reisen WK, Scott TW. 2003. Vertical transmission of West Nile virus by three California Culex (Diptera: Culicidae) species. Journal of Medical Entomology, 40, 743-746.

20. Goldblum N, Sterk V, Paderski B. 1954. West Nile fever; the clinical features of the disease and the isolation of West Nile virus from the blood of nine human cases. American Journal of Hygiene, 59, 89-103.

21. Han LL, Popovici F, Alexander JP, Laurentia V, Tengelsen LA, Cernescu C, Gary HE, Ion-Nedelcu N, Campbell GL, Tsai TF. 1999. Risk factors for West Nile virus infection and meningoencephalitis, Romania, 1996. Journal of Infectious Diseases, 179, 230-233.

22. Harbach RE. 2007. The Culicidae (Diptera): a review of taxonomy, classification and phylogeny. Zootaxa, 1668, 591-638.

23. Hayes CG. 1989. West Nile fever, in Arboviruses: epidemiology and ecology. Monath TP, Editor. Florida: Boca Raton. p. 59-88.

24. Hernández-Triana L, Jeffries C, Mansfield K, Carnell G, Fooks A, Johnson N. 2014. Emergence of West Nile virus lineage 2 in Europe: a review on the introduction and spread of a mosquito-borne disease. Frontiers in Public Health, $2,1-8$.

25. Hubálek Z, Halouzka J. 1999. West Nile Fever, a reemerging mosquito-borne viral disease in Europe. Emerging Infectious Diseases, 5, 643-650.

26. Jupp P. 2001. The ecology of West Nile virus in South Africa and the occurrence of outbreaks in humans. Annals of the New York Academy of Sciences, 951, 143-512.

27. Kent R, Juliusson L, Weissmann M, Evans S, Komar N. 2009. Seasonal blood-feeding behavior of Culex tarsalis (Diptera: Culicidae) in Weld county, Colorado, 2007. Journal of Medical Entomology, 46, 380-390.

28. Kiener A. 1963. Poissons, Pêche et Pisciculture à Madagascar. Centre Technique Forestier Tropical, Nogent sur Marne, France, 24, 1-244.

29. Krockel U, Rose A, Eiras A, Geier M. 2006. New tools for surveillance of adult yellow fever mosquitoes: comparison of trap catches with human landing rates in an urban environment. Journal of the American Mosquito Control Association, 22, 229-238.

30. Lanciotti RS, Ebel GD, Deubel V, Kerst AJ, Murri S, Meyer R, Bowen M, McKinney N, Morrill WE, Crabtree MB, Kramer LD, Roehrig JT. 2002. Complete genome sequences and phylogenetic analysis of West Nile virus strains isolated from the United States, Europe and the Middle East. Virology, 298, 96-105.

31. Larrieu S, Cardinale E, Ocquidant P, Roger M, Lepec R, Delatte H, Camuset G, Desprès P, Brottet E, Charlin C, Michault A. 2013. Case report: a fatal neuroinvasive West Nile virus infection in a traveler returning from Madagascar: clinical, epidemiological and veterinary investigations.
American Journal of Tropical Medicine and Hygiene, 89, 211-213.

32. Linke S, Ellerbrok H, Niedrig M, Nitsche A, Pauli G. 2007. Detection of West Nile virus lineages 1 and 2 by real-time PCR. Journal of Virological Methods, 146, 355-358.

33. Lonchampt C, Migliani R, Ratsitorahina M, Rabarijaona LP, Ramarokoto CE, Rakoto Andrianarivelo M, Rousset D. 2003. Persistance d'une circulation endémique du virus West Nile à Madagascar. Archives de l'Institut Pasteur de Madagascar, 69, 33-36.

34. Lutomiah JL, Koka H, Mutisya J, Yalwala S, Muthoni M, Makio A, Limbaso S, Musila L, Clark JW, Turell MJ, Kioko E, Schnabel D, Sang RC. 2011. Ability of selected Kenyan mosquito (Diptera: Culicidae) species to transmit West Nile virus under laboratory conditions. Journal of Medical Entomology, 48, 1197-1201.

35. Mantilla-Contreras J, Carrière S. 2015. Madagascar's open landscapes under the spotlight. Madagascar Conservation and Development, 10, 107-109.

36. Maquart M, Boyer S, Rakotoharinome VM, Ravaomanana J, Tantely ML, Heraud J, Cardinale E. 2015. High prevalence of West Nile virus in domestic birds and detection in 2 new potential mosquito vectors in Madagascar. PloS One, 11, e0147589.

37. Mathiot $\mathrm{CH}$, Clerc Y, Rodhain F, Digoutte JP, Coulanges P. 1983. Le virus West-Nile et Madagascar. Archives de l'Institut Pasteur de Madagascar, 51, 113-124.

38. McIntosh B, McGillivray G, Dickinson D. 1964. Illness caused by Sindbis and West Nile viruses in South Africa. South African Medical Journal, 38, 291-294.

39. McIntosh BM, Jupp PG, Dossantos I, Meenehan GM. 1976. Epidemics of West Nile and Sindbis Viruses in South Africa with Culex (Culex) univittatus Theobald as vector. South African Journal of Science, 72, 295-300.

40. Meyrowitsch D, Pedersen E, Alifrangis M, Scheike T, Malecela M, Magesa S, Derua Y, Rwegoshora R, Michael E, Simonsen P. 2011. Is the current decline in malaria burden in sub-Saharan Africa due to a decrease in vector population? Malaria Journal, 10, 188.

41. Miller BR, Nasci RS, Godsey MS, Savage HM, Lutwama JJ, Lanciotti RS, Peters CJ. 2000. First field evidence for natural vertical transmission of West Nile virus in Culex univittatus complex mosquitoes from Rift Valley province, Kenya. American Journal of Tropical Medicine and Hygiene, 62, 240-246.

42. Molaei G, Cummings R, Su T, Armstrong P, Williams G, Cheng M, Webb J, Andreadis T. 2010. Vector-host interactions governing epidemiology of West Nile virus in Southern California. American Journal of Tropical Medicine and Hygiene, 83, 1269-1282.

43. Morvan J, Chin L, Fontenille D, Rakotoarivony I, Coulanges P. 1991. Prévalence des anticorps antivirus West Nile chez les jeunes de 5 à 20 ans à Madagascar. Bulletin de la Société de Pathologie Exotique, 84, 225-234.

44. Motayo B, Onoja B, Faneye A, Adeniji J. 2016. Seasonal abundance and molecular identification of West Nile virus vectors, Culex pipens and Culex quinquefasciatus (Diptera: Culicidae) in Abeokuta, South-West, Nigeria. African Health Sciences, 16, 135-140.

45. Murgue BZH, Deubel V. 2002. The ecology and epidemiology of West Nile virus in Africa, Europe and Asia. Current Topics in Microbiology Immunology, 267, 195-221. 
46. Nepomichene TNJJ, Elissa N, Cardinale E, Boyer S. 2015. Species diversity, abundance, and host preferences of mosquitoes (Diptera: Culicidae) in two different ecotypes of Madagascar with recent RVFV transmission. Journal of Medical Entomology, 52, 962-969.

47. Philip CB, Smadel JE. 1943. Transmission of West Nile virus by infected Aedes albopictus. Proceedings of the Society for Experimental Biology and Medicine, 48, 537-548.

48. Reisen W, Fang Y, Martinez V. 2005. Avian host and mosquito (Diptera: Culicidae) vector competence determine the efficiency of West Nile and St. Louis encephalitis virus transmission. Journal of Medical Entomology, 42, 367-375.

49. Riabi S, Gallian P, Gaaloul I, Simon S, Harrath R, Hassine M, de Micco P, Aouni M. 2010. Prevalence of IgG antibodies against West Nile virus in blood donors during the 2003 outbreak in Tunisia. Transaction of the Royal Society of Tropical Medicine and Hygiene, 104, 507-509.

50. Richards S, Mores C, Lord C, Tabachnick W. 2007. Impact of extrinsic incubation temperature and virus exposure on vector competence of Culex pipiens quinquefasciatus (Diptera: Culicidae) for West Nile virus. Vector Borne and Zoonotic Diseases, 7, 629-636.

51. Ruiz MO, Chaves LF, Hamer GL, Sun T, Brown WM, Walker ED, Haramis L, Goldberg TL, Kitron UD. 2010. Local impact of temperature and precipitation on West Nile virus infection in Culex species mosquitoes in northeast Illinois, USA. Parasites and Vectors, 3, 1-16.

52. Savage HM, Ceianu C, Nicolescu G, Karabatsos N, Lanciotti R, Vladimirescu A, Laiv L, Ungureanu A, Romanca C, Tsai TF. 1999. Entomologic and avian investigations of an epidemic of West Nile fever in Romania in 1996, with serologic and molecular characterization of a virus isolate from mosquitoes. American Journal of Tropical Medicine and Hygiene, 61, 600-611.

53. Smithburn K, Jacobs H. 1942. Neutralization tests against neurotropic viruses with sera collected in Central Africa. Journal of Immunology, 44, 9-23.
54. Smithburn KC, Hughes TP, Burke AW, Paul JH. 1940. A neurotropic virus isolated from the blood of a native of Uganda. American Journal of Tropical Medicine and Hygiene, 20, 471-492.

55. Tantely ML, Rakotoniaina JC, Andrianaivolambo L, Tata E, Fontenille D, Elissa N. 2012. Modification of distribution of Anopheles gambiae, a malaria vector, at high altitude in Madagascar. Journal of Vector Ecology, 37, 402-406.

56. Tantely ML, Rakotoniaina JC, Andrianaivolambo L, Tata E, Razafindrasata F, Fontenille D, Elissa N. 2013. Biology of mosquitoes that are potential vectors of Rift Valley fever virus in different biotopes of the Central Highlands of Madagascar. Journal of Medical Entomology, 50, 603-610.

57. Tantely M, Goodman S, Rakotondranaivo T, Boyer S. 2016. Review of West Nile virus circulation and outbreak risk on Madagascar: entomological and ornithological perspectives. Parasite, 23, 49.

58. Tantely ML, Le Goff G, Boyer S, Fontenille D. 2016. An updated checklist of mosquito species (Diptera: Culicidae) from Madagascar. Parasite, 23, 20.

59. Traore-Lamizana M, Zeller HG, Mondo M, Hervy JP, Adam F, Digoutte JP. 1994. Isolations of West Nile and Bagaza viruses from mosquitoes (Diptera: Culicidae) in Central Senegal (Ferlo). Journal of Medical Entomology, 5, 934-938.

60. Turell M, Dohm DJ, Sardelis MR, O'Guinn ML, Andreadis TG, Blow JA. 2005. An update on the potential of North American mosquitoes (Diptera: Culicidae) to transmit West Nile virus. Journal of Medical Entomology, 42, 57-62.

61. Unlu I, Mackay AJ, Roy A, Yates MM, Foil LD. 2010. Evidence of vertical transmission of West Nile virus in field-collected mosquitoes. Journal of Vector Ecology, 35, 95-99.

62. Venter M, Swanepoel R. 2010. West Nile virus lineage 2 as a cause of zoonotic neurological disease in humans and horses in southern Africa. Vector Borne and Zoonotic Diseases, 10, 659-664.

Cite this article as: Tantely LM, Cêtre-Sossah C, Rakotondranaivo T, Cardinale E \& Boyer S: Population dynamics of mosquito species in a West Nile virus endemic area in Madagascar. Parasite, 2017, 24, 3.

Reviews, articles and short notes may be submitted. Fields include, but are not limited to: general, medical and veterinary parasitology; morphology, including ultrastructure; parasite systematics, including entomology, acarology, helminthology and protistology, and molecular analyses; molecular biology and biochemistry; immunology of parasitic diseases; host-parasite relationships; ecology and life history of parasites; epidemiology; therapeutics; new diagnostic tools.

All papers in Parasite are published in English. Manuscripts should have a broad interest and must not have been published or submitted elsewhere. No limit is imposed on the length of manuscripts.

Parasite (open-access) continues Parasite (print and online editions, 1994-2012) and Annales de Parasitologie Humaine et Comparée (1923-1993) and is the official journal of the Société Française de Parasitologie. 